\title{
Photocatalytic degradation of methylene blue dye under visible light irradiation using $\mathrm{In} / \mathrm{ZnO}$ nanocomposite
}

\author{
ES Baeissa \\ Chemistry Department, Faculty of Science, King Abdulaziz University, Saudi Arabia
}

\begin{abstract}
A sol- gel method was used to prepare $\mathrm{ZnO}$ nanoparticles, and a photo-assisted deposition method was used to deposit indium into the surface of $\mathrm{ZnO}$ nanoparticles. BET, XRD, XPS, P1, UV-Vis and TEM measurements were used to characterize the $\mathrm{ZnO}$ and $\mathrm{Pt} / \mathrm{ZnO}$ nanoparticles. The photocatalytic oxidation of methylene blue dye under visible light irradiation was used to determine the photocatalytic performance of the prepared nanoparticles. The results demonstrated that the indium was well dispersed on the surface of the $\mathrm{ZnO}$ nanoparticles. Additionally, the surface area of the $\mathrm{In} / \mathrm{ZnO}$ nanoparticles was smaller than that of the $\mathrm{ZnO}$ nanoparticles because some of the pores of the $\mathrm{ZnO}$ nanoparticles were blocked by the deposited In metal. The In/ $\mathrm{ZnO}$ nanoparticles (0.6 wt $\%)$ exhibited the lowest band gap and the highest photocatalytic activity for the methylene blue dye. The photocatalytic performance of the $0.6 \mathrm{wt} \% \mathrm{In} / \mathrm{ZnO}$ nanoparticles was stable after the nanoparticles were reused five times for the oxidation of methylene blue dye.
\end{abstract}

\section{Introduction}

In recent years, the contamination of surface and ground water has increased due to population growth. The main sources of environmental contamination are organic dyes used in the food and textile industries due to their high toxicity and their nonbiodegradability, which have carcinogenic effects on humans. MB dye is used by different industries, for example, as a dye in silk; as a food colouring additive; and as a dye in wool, leather, cotton, jute, and paper [1-3]. Methylene blue dyes have strong effects on the immune and reproductive systems and exhibit potential carcinogenic and genotoxic effects [4,5]. Thus, these hazardous dyes must be removed from industrial effluents. Many methods, such as biological treatment [6,7], adsorption [8], and photocatalysis [9-13], have been used for removal of these dyes from industrial effluents. The use of photocatalysts to degrade organic compounds in contaminated air or water or to convert them into harmless chemicals has been extensively studied to decrease the damage caused by organic dye pollution to the environment and humans [14]. Therefore, heterogeneous photocatalysis is an interesting area of research because the method allows for complete mineralization of these environmentally hazardous dyes [13]. Among a variety of photocatalysts, $\mathrm{TiO}_{2}$ is the most common photocatalyst due to its non-toxicity, good activity and high resistance to corrosion. One of the disadvantages for the use of titanium dioxide is its absorption in the UV region, which represents approximately $5 \%$ of sunlight. Therefore, the absorption of the photocatalyst must be altered to move it from the UV to visible region. Many methods have been studied to extend the absorption of photocatalysts from the UV to the visible region, such as variation of the titanium dioxide by metal or non-metal $[14,15]$. Other attempts have focused on preparing new photocatalysts, such as multi-metal oxide photocatalysts [16-19]. Zinc Oxide ( $\mathrm{ZnO})$ belongs to a category of n-type semiconductors having wide energy band gap of $3.37 \mathrm{eV}$. Recently, $\mathrm{ZnO}$ has attracted much attention as a promising photocatalytic material for removal of organic pollutants, which present in wastewater, all because of its high catalytic activity, moderate preparation cost and environmentally benign nature [20-
23]. Nanoscale $\mathrm{ZnO}$ particles possess significant surface area and large number of active sites ensure increased surface catalyzed reaction rates thus promoting photocatalysis [24]. However, the large energy band gap of $\mathrm{ZnO}$ permits electronic excitations only with photons having energy below $400 \mathrm{~nm}$ (UV spectrum). High degree of recombination of photogenerated species is another limitation associated with $\mathrm{ZnO}$ which is responsible for low photocatalytic activity [25-28]. These shortfalls can be remediated by modifying $\mathrm{ZnO}$ such as to extend its absorption threshold to the visible spectrum and limiting the rate of electron/hole pair recombination. Different attempts were achieved recently to improve the activity of $\mathrm{ZnO}$ photocatalyst. Development of nanoscale core/shell materials is a worth mentioning technique receiving considerable attraction [29,30]. The functional groups attached on the outer shell provide with the surface charge and reactivity to the surface and may also help to stabilize and provide equal dispersion of the core material. On other hand the characteristic catalytic, optoelectronic or magnetic properties of the shell may also be imparted to the core particles. The main aim to synthesize core/ shell structured materials is to achieve a mix of the best qualities of the components in the composite materials. A number of studies focused on the synthesis of composite materials such as; $\mathrm{NiO}$ [31], $\mathrm{V}_{2} \mathrm{O}_{5}$ [32], $\mathrm{TiO}_{2}$ [33], $\mathrm{Fe}_{2} \mathrm{O}_{3}$ [34], $\mathrm{Pt}$ [35], and $\mathrm{Ag}$ [36-37] with $\mathrm{SiO}_{2}$ coatings have been reported. $\mathrm{SiO}_{2}$ has been given significant consideration as a shell candidate based on easy preparation, environmental friendliness and conformity with most other materials, which provides and ample motivation to synthesize the $\mathrm{ZnO}$ and $\mathrm{SiO}_{2}$ core/shell structured composite with expectation of achieving novel photocatalytic

Correspondence to: Elham Baeissa, Chemistry Department, Faculty of Science, King Abdulaziz University, P.O. Box 80203 Jeddah 21589, Saudi Arabia, Tel.: +966-6400000; Fax: +966-2-6952292E-mail: elhambaeissa@gmail.com

Key words: $\mathrm{ZnO}$, indium doping, photocatalyst, methylene blue dye oxidation

Received: October 14, 2016; Accepted: October 29, 2016; Published: October 31,2016 
properties from their synergic interaction. Surface modification by metal doping of photocatalytically active material has shown much promise towards increase in photocatalytic efficiency. The dopant ions act as electron sinks thus prevent the recombination of photogenerated holes with electrons, therefore, charge separation will be increased [38-41]. The physicochemical properties of $\mathrm{ZnO}$ nanoparticles can be altered by doping with mixed metal oxides to facilitate chargetransfer and promote its photocatalytic applications. Metal ions for instance, Iron (Fe) [42] and silver ( $\mathrm{Ag}$ ) $[43,44]$ when used as dopants have been reported to improve the photocatalytic activity of $\mathrm{ZnO}$. A number of controlling factors such as particle dimensions, number of actives sites, energy band gap, and stability of photogenerated species can decide the efficiency of a photocatalyst [45]. Researchers have investigated alternative routes such as multicomponent oxide catalysts, doping and altering synthesis techniques to add desired characteristics to the catalysts of choice [46-50]. However, the above methods required complicated procedures, special equipment or organometallic precursors. Therefore, the great challenge of fabricating $\mathrm{ZnO}$ nanocrystals with uniform size and well-defined crystal shape still remains. Thus, the efficiency of visible-light-harvesting was increased by increasing the optical path length of photons and surface area, which can be achieved by preparing a mesoporous semiconductor/ metal composite. In this work, a In/ZnO nanoparticles were prepared by a sol-gel method. The photocatalytic performance of the prepared materials was studied by the photocatalytic degradation of methylene blue dye using visible light irradiation.

\section{Experimental}

\section{Preparation of photocatalyst}

$\mathrm{ZnO}$ nanoparticles were synthesized via a sol-gel technique. In a typical procedure, $20 \mathrm{ml}$ zinc methoxide was mixed with methyl alcohol, ultra pure water $\left(\mathrm{H}_{2} \mathrm{O}\right)$ and nitric acid $\left(\mathrm{HNO}_{3}\right)$ under vigorous stirring for $1 \mathrm{hr}$. The prepared samples were aged at room temperature till form a gel. Finally, the samples were evaporated and dried at $80^{\circ} \mathrm{C}$, followed by calcination at $550^{\circ} \mathrm{C}$ for $5 \mathrm{~h}$ in air.

A photo-assisted deposition method was used to prepare $\mathrm{In} / \mathrm{ZnO}$. Typically, $\mathrm{ZnO}$ was impregnated in an aqueous solution of $\mathrm{InCl}_{3} .4 \mathrm{H}_{2} \mathrm{O}$ (containing $0.2,0.4,0.6$ or $0.8 \mathrm{wt} \%$ of In). Then, the resulting mixture was exposed to UV irradiation for $24 \mathrm{~h}$. The obtained sample was dried for $24 \mathrm{~h}$ at $60^{\circ} \mathrm{C}$.

\section{Characterization techniques}

A Bruker axis D8 instrument with $\mathrm{Cu}$ Ka radiation $(\lambda=1.540 \AA)$ was used for X-ray diffraction (XRD) analysis, which was performed at room temperature. $\mathrm{N}_{2}$ adsorption measurements were conducted using a Nova 2000 series Chromatech apparatus at $77 \mathrm{~K}$ to calculate the surface area. The samples were treated for two hours under vacuum at $100^{\circ} \mathrm{C}$ before taking the measurements. UV-visible diffuse reflectance spectroscopy (UV-Vis-DRS) was used to display the performance of the sample band gaps of samples. The spectroscopy was conducted in air at room temperature using a UV/Vis/NIR spectrophotometer (V570 , JASCO, Japan) in the wavelength range of 200 to $800 \mathrm{~nm}$. A JEOL JEM-1230 microscope was used for transmission electron microscopy (TEM). The samples were entirely placed in a suspension of ethanol and then ultrasonicated for half an hour. A small amount of solution was placed on a copper grid, coated with carbon and left to dry. After the solution was dry, the sample was loaded into the TEM. A Shimadzu RF-5301 fluorescence spectrophotometer was used for recording the photoluminescence $(\mathrm{Pl})$ emission spectra.

\section{Photocatalysis experiment}

A xenon lamp $\left(300 \mathrm{~W}\right.$ power and $0.96 \mathrm{~W} / \mathrm{cm}^{2}$ intensity with a cutoff filter of $420 \mathrm{~nm}$ ) was used to study the photocatalytic degradation of methylene blue dye. Prior to the photocatalytic test, the photocatalyst was suspended in an aqueous solution of methylene blue dye in a 500 $\mathrm{ml}$ reactor. Then, the obtained mixture was stirred for $30 \mathrm{~min}$ in the dark to establish the adsorption-desorption equilibrium. At different time intervals, samples from the mixture were taken and filtered for analysis. The absorbance of the samples were analyzed using a spectrophotometer.

\section{Results and discussion}

\section{Structural, morphological and compositional characterizations}

Figure 1 shows the XRD patterns of the $\mathrm{ZnO}$ and $\mathrm{In} / \mathrm{ZnO}$ nanoparticles. The results reveal that all samples were mainly composed of $\mathrm{ZnO}$, which indicates that the lack of diffraction peaks due to indium in the patterns of the $\mathrm{In} / \mathrm{ZnO}$ samples, because the indium wt\% was below the XRD detection limit or because indium was well dispersed on surface of $\mathrm{ZnO}$ nanoparticles.

Figure 2 shows TEM images of the $\mathrm{ZnO}$ and $\mathrm{In} / \mathrm{ZnO}$ nanoparticles. The results show that increased indium $w t \%$, the indium dispersion increased on the surface of the $\mathrm{ZnO}$ nanoparticles. Additionally, increased indium $w t \%$ up to $0.6 \%$ increased the homogeneity of the In particle size on the surface of the $\mathrm{ZnO}$ nanoparticles. This homogeneity decreased at higher concentrations of In, i.e., $0.6 \mathrm{wt} \%$, which suggests that there is an optimum content for the deposition of indium ions that controls the size and homogeneity of the doped indium (Figure 3).

\section{Surface area analysis}

BET surface area of $\mathrm{ZnO}$ and $\mathrm{In} / \mathrm{ZnO}$ nanoparticles are presented in Table 1. The $\mathrm{S}_{\mathrm{BET}}$ values for $\mathrm{ZnO} 0.2 \mathrm{wt} \% \mathrm{In} / \mathrm{ZnO}, 0.4 \mathrm{wt} \% \mathrm{In} / \mathrm{ZnO}$, $0.6 \mathrm{wt} \% \mathrm{In} / \mathrm{ZnO}$ and $0.4 \mathrm{wt} \% \mathrm{In} / \mathrm{Z} \mathrm{nO}$ were determined to be 50,46 , 44,40 and $38 \mathrm{~m}^{2} / \mathrm{g}$, respectively. The BET surface area of $\mathrm{In} / \mathrm{ZnO}$ nanoparticle was lower than that of the $\mathrm{ZnO}$ sample because some of the pores were blocked by the deposited of indium.

\section{Optical characterization}

Figure 4 shows the UV-Vis diffuse reflectance spectra of the $\mathrm{ZnO}$ and $\mathrm{In} / \mathrm{ZnO}$ nanoparticles. The results demonstrate that the deposition of indium onto the $\mathrm{ZnO}$ surface led to a shift in the absorption edge of $\mathrm{ZnO}$ from $387 \mathrm{~nm}$ to $454 \mathrm{~nm}$. The UV-Vis spectra were used to calculate the direct band gaps of the $\mathrm{ZnO}$ and $\mathrm{Pt} / \mathrm{ZnO}$ nanoparticles.

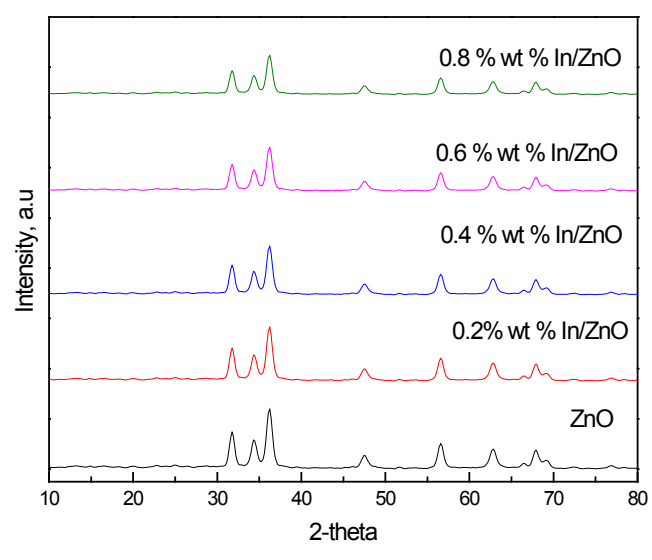

Figure 1. $\mathrm{XRD}$ patterns of $\mathrm{ZnO}$ and $\mathrm{In} / \mathrm{ZnO}$ nanoparticles. 


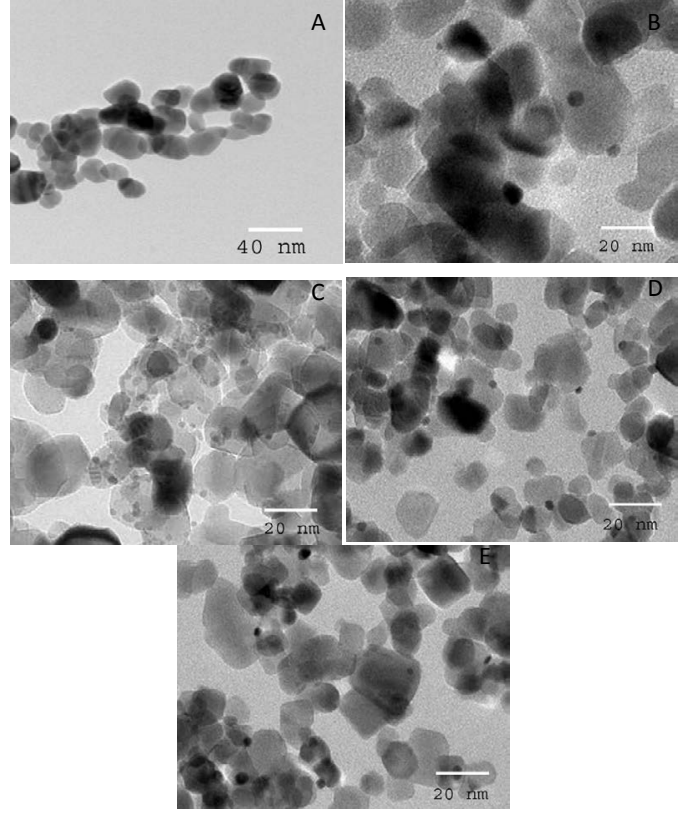

Figure 2. TEM images of $\mathrm{ZnO}$ and $\mathrm{In} / \mathrm{ZnO}$ nanoparticles, where the $\mathrm{In} \mathrm{wt} \%$ is $0.0(\mathrm{~A}) ; 0.2$ (B); 0.4 (C); 0.6 (D) and 0.8 (E).

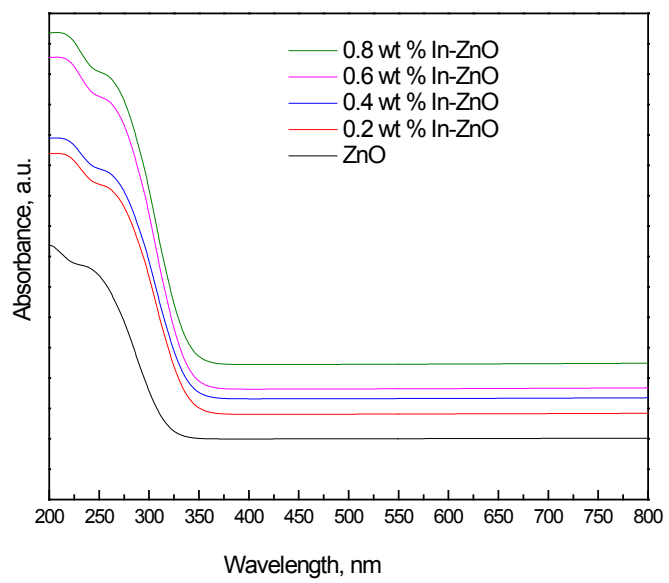

Figure 3. UV-Vis absorption spectra of $\mathrm{ZnO}$ and $\mathrm{In} / \mathrm{ZnO}$ nanoparticles.

Table 1. BET surface area of $\mathrm{ZnO}$ and $\mathrm{In} / \mathrm{ZnO}$ nanoparticles.

\begin{tabular}{|c|c|}
\hline Sample & $\begin{array}{c}\mathbf{S}_{\text {BET }} \\
\left(\mathbf{m}^{2} / \mathbf{g}\right)\end{array}$ \\
\hline $\mathrm{ZnO}$ & 50.00 \\
\hline $0.2 \mathrm{wt} \% \mathrm{In} / \mathrm{ZnO}$ & 46.00 \\
\hline $0.4 \mathrm{wt} \% \mathrm{In} / \mathrm{ZnO}$ & 44.00 \\
\hline $0.6 \mathrm{wt} \% \mathrm{In} / \mathrm{ZnO}$ & 40.00 \\
\hline $0.8 \mathrm{wt} \% \mathrm{In} / \mathrm{ZnO}$ & 38.00 \\
\hline
\end{tabular}

The band gap energies were calculated using the following equation:

$$
\mathrm{E}_{\mathrm{g}}=1239.8 / \lambda
$$

where $\mathrm{E}_{\mathrm{g}}$ is the band gap $(\mathrm{eV})$ and $\lambda$ is the wavelength $(\mathrm{nm})$ of the absorption edges in the spectrum; the results are tabulated in Table 2. The results reveal that increasing the In wt $\%$ from $0.2 \mathrm{wt} \%$ to $0.6 \mathrm{wt} \%$ decreased the band gap from $3.2 \mathrm{eV}$ to $2.73 \mathrm{eV}$, respectively. However, there was no significant effect on the band gap at a high wt $\%$ of In (greater than 0.6 ). Therefore, there is an optimum content of deposited In that controls the band gap.
We investigated the separation and recombination of photogenerated charge carriers and the transfer of the photogenerated electrons and holes by gathering photoluminescence $(\mathrm{Pl})$ emission spectra. The results indicate that an increase in the wt $\%$ of In deposited on the $\mathrm{ZnO}$ nanoparticles from $0.2 \mathrm{wt} \%$ to $0.6 \mathrm{wt} \%$ led to decreased $\mathrm{Pl}$ intensity. However, there was no significant effect on the Pl intensity at a high in wt\% (above 0.6), as shown in Figure 4. Therefore, there is an optimum content of deposited in that yields the carrier lifetime required for e-h recombination, which is in agreement with the UVVis results.

\section{Photocatalytic activities}

Figure 5 shows the effect of the In wt $\%$ on the photocatalytic activity of $\mathrm{ZnO}$ and $\mathrm{In} / \mathrm{ZnO}$ nanoparticles for the oxidation of methylene blue dye under visible light irradiation. The experiment was performed under the following conditions: methylene blue dye concentration of $100 \mathrm{ppm}$, methylene blue dye volume of $1000 \mathrm{ml}$ and photocatalyst

Table 2. Band gap energies $\mathrm{ZnO}$ and $\mathrm{In} / \mathrm{ZnO}$ nanoparticles.

\begin{tabular}{|c|c|}
\hline Sample & Band gap energy, eV \\
\hline $\mathrm{ZnO}$ & 3.20 \\
\hline $0.2 \mathrm{wt} \% \mathrm{In} / \mathrm{ZnO}$ & 2.95 \\
\hline $0.4 \mathrm{wt} \% \mathrm{In} / \mathrm{ZnO}$ & 2.83 \\
\hline $0.6 \mathrm{wt} \% \mathrm{In} / \mathrm{ZnO}$ & 2.73 \\
\hline $0.8 \mathrm{wt} \% \mathrm{In} / \mathrm{ZnO}$ & 2.62 \\
\hline
\end{tabular}

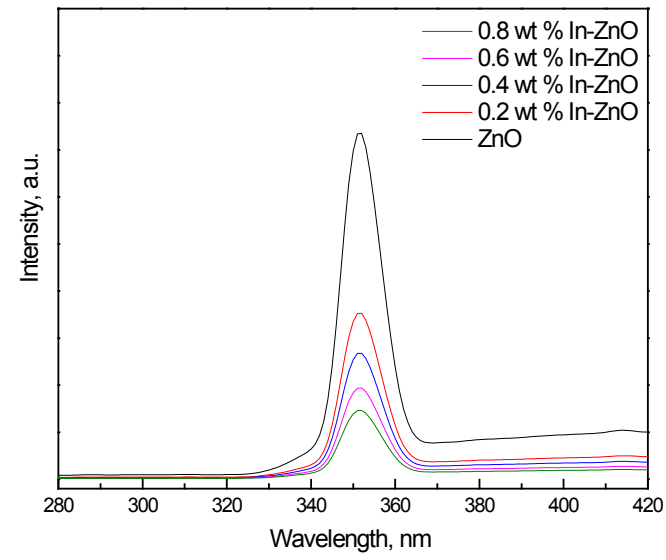

Figure 4. $\mathrm{Pl}$ spectra of $\mathrm{ZnO}$ and $\mathrm{In} / \mathrm{ZnO}$ nanoparticles.

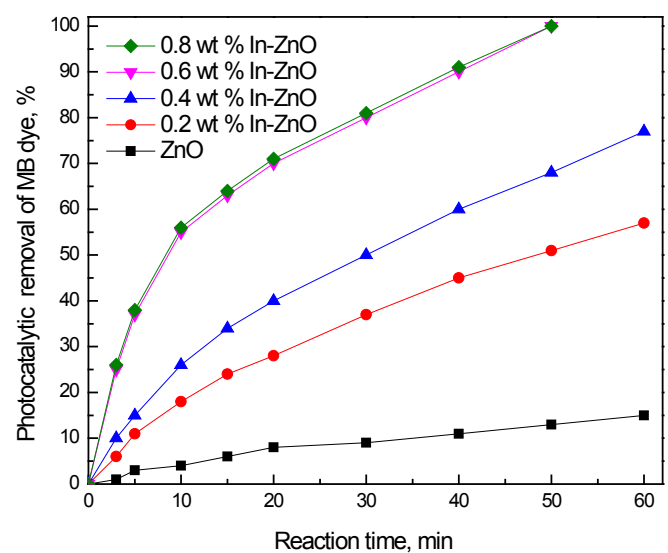

Figure 5. Effect of the In $\mathrm{wt} \%$ on the photocatalytic activity of $\mathrm{ZnO}$ and $\mathrm{In} / \mathrm{ZnO}$ nanoparticles for the oxidation of methylene blue dye. 
weight of $0.75 \mathrm{~g}$. The results reveal that the photocatalytic activity increased from 15 to $100 \%$ as the indium wt $\%$ increased from 0 to 0.6 $\mathrm{wt} \%$. However, further increasing the indium $\mathrm{wt} \%$ above $0.6 \mathrm{wt} \%$ has no significant effect on photocatalytic activity.

Figure 6 shows the effect the loading of the $0.6 \mathrm{wt} \% \mathrm{In} / \mathrm{ZnO}$ sample on the photocatalytic oxidation of methylene blue dye solution under visible light irradiation; the experiment was performed under the following conditions: methylene blue dye concentration of 100 ppm, methylene blue dye volume of $1000 \mathrm{ml}$ and a $0.6 \mathrm{wt} \% \mathrm{In} / \mathrm{ZnO}$ nanoparticles photocatalyst. The results reveal that photocatalytic performance, in terms of the percentage, increased after $50 \mathrm{~min}$ from $97 \%$ to $100 \%$ with increased weight of the photocatalyst from 0.50 $\mathrm{g} / \mathrm{l}$ to $0.75 \mathrm{~g} / \mathrm{l}$. The reaction time required to complete the oxidation of methylene blue dye decreased to $30 \mathrm{~min}$ as the weight of the photocatalyst was increased to $1.0 \mathrm{~g} / \mathrm{l}$. However, the reaction time required to complete the oxidation of methylene blue dye increased again to 45 , and $55 \mathrm{~min}$ as the weight of the photocatalyst increased to $1.25 \mathrm{~g} / \mathrm{l}$ and $1.50 \mathrm{~g} / \mathrm{l}$, respectively. Therefore, the optimum weight of the photocatalyst is $1.0 \mathrm{~g} / \mathrm{l}$.

Figure 7 shows the results obtained regarding the recycling and reuse of the photocatalysts for photocatalytic oxidation of methylene blue dye solutions. The experiment was carried out under the following conditions: reaction time of $30 \mathrm{~min}$, methylene blue dye solution concentration of $100 \mathrm{ppm}$ and $1.0 \mathrm{~g} / \mathrm{l}$ of the $0.6 \mathrm{wt} \% \mathrm{In} /$

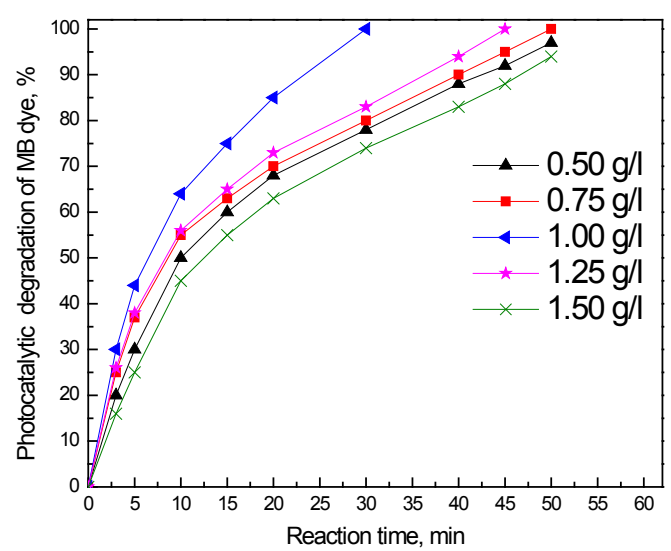

Figure 6. Effect of the loading of the $0.6 \mathrm{wt} \% \mathrm{In} / \mathrm{ZnO}$ sample on the photocatalytic oxidation of methylene blue dye.

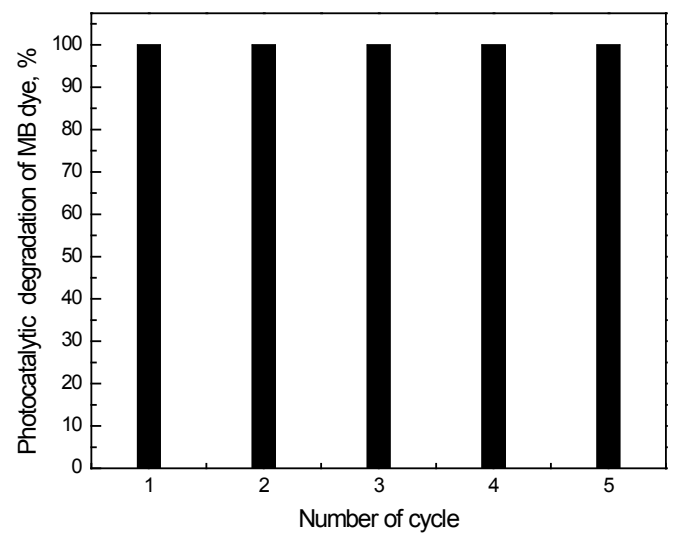

Figure 7. Recycling and reuse of $0.6 \mathrm{wt} \% \mathrm{In} / \mathrm{ZnO}$ photocatalysts for the photocatalytic oxidation of methylene blue dye solutions.
$\mathrm{ZnO}$ nanoparticle. The results show that the photocatalytic activity remained nearly unchanged after five uses, which indicates that the photocatalyst is stable in the photocatalytic oxidation of methylene blue dye solutions. Therefore, this photocatalyst can be separated and recycled while maintaining its stability, making it a promising material for environmental remediation.

\section{Conclusions}

In summary, a In/ZnO nanoparticle photocatalyst was successfully synthesized and was demonstrated to be a promising catalyst due to its high efficiency in oxidizing methylene blue dye under visible light. The band gap of the $\mathrm{ZnO}$ photocatalyst could be controlled by controlling the weight percent of indium that is deposited onto the surface of the photocatalyst. The results of photocatalytic studies reveal that the highest photocatalytic activity and stability were obtained for the 0.6 $\mathrm{wt} \% \mathrm{In} / \mathrm{ZnO}$ nanoparticle photocatalyst, which can be used to oxidize $100 \%$ of methylene blue dye after $30 \mathrm{~min}$.

\section{References}

1. Sarmah S, Kumar A (2008) Photocatalytic activity of polyaniline-TiO2 nanocomposites. Indian J Phys. 85: 713-726.

2. Srivastava S, Sinha R, Roy D (2004) Toxicological effects of malachite green. Aquat Toxicol 66: 319-329. [Crossref]

3. Cheng W, Wang SG, Lu L, Gong WX, Liu XW, et al. (2008) Interaction between congo red and copper in a binary adsorption system: Spectroscopic and kinetic studies. Biochem.Eng $J$ 538-546.

4. Rao KV (1995) Inhibition of DNA synthesis in primary rat hepatocyte cultures by malachite green: a new liver tumor promoter. Toxicol Lett 81: 107-113. [Crossref]

5. Alderman DJ, Clifton-Hadley RS (1993) Malachite green: a pharmacokinetic study in rainbow trout, Oncorhynchus mykiss (Walbaum). J Fish Dis 16 297-311.

6. Ramezani S, Pourbabaee AA, Javaheri JA, Bioremed J (2013) Photocatalytic performance of $\mathrm{ZnO}$ nanomaterials for self-sensitized degradation of malachite green dye under solar light. Biodegrad 4: 1000175.

7. Wang J, Qiao M, Wei K, Ding J, Liu Z, et al. (2011) Decolorizing activity of malachite green and its mechanisms involved in dye biodegradation by Achromobacter xylosoxidans MG. J Mol Microbiol Biotechnol 20: 220-227. [Crossref]

8. Mittal A (2006) Adsorption kinetics of removal of a toxic dye, Malachite Green, from wastewater by using hen feathers. J Hazard Mater 133: 196-202. [Crossref]

9. Sayilkan M, Asilturk M, Tatar P, Kiraz N, Arpac E, et al. (2007) Preparation of reusable photocatalytic filter for degradation of Malachite Green dye under UV and visirradiation. J Hazard Mater 148: 735-744.

10. Chen CC, Lu CS, Chung YC, Jan JL (2007) UV light induced photodegradation of malachite green on TiO2 nanoparticles. J Hazard Mater 141: 520-528. [Crossref]

11. Pare B, Sarwan B, Jonnalagadda SB (2011) Photocatalytic mineralization study of malachite green on the surface of $\mathrm{Mn}$-doped $\mathrm{BiOCl}$ activated by visible light under ambient condition. Appl Surf Sci 258: 247-253.

12. Liu Y, Ohko Y, Zhang R, Yang Y, Zhang Z (2010) Degradation of malachite green on $\mathrm{Pd} / \mathrm{WO} 3$ photocatalysts under simulated solar light. J Hazard Mater 184: 386-391. [Crossref]

13. Prado AG, Costa LL (2009) Photocatalytic decouloration of malachite green dye by application of TiO2 nanotubes. J Hazard Mater 169: 297-301. [Crossref]

14. Herrmann JM, Disdier M, Pichat P (1984) Effect of chromium doping on the electrical and catalytic properties of powder titania under UV and visible illumination. Chemical Physics Letters 108: 618-622.

15. Cheng ZJ, Liu TY, Chen XY, Gan HX, Zhang FW, et al. (2012) Study on the electronic structures of the reduced anatase $\mathrm{TiO} 2$ by the first-principle calculation. Journal of Physics and Chemistry of Solids 73: 302-307.

16. Tang J, Zou Z, Ye J (2004) Efficient photocatalytic decomposition of organic contaminants over $\mathrm{CaBi} 2 \mathrm{O} 4$ under visible-light irradiation. Angew Chem Int Ed Engl 43: 4463-4466. [Crossref]

17. Li ZH, Dong Z, Zhang YF, Dong TT, Wang XX, et al. (2008) Effect of M2+ (M= Zn 
and $\mathrm{Cu}$ ) Dopants on the Electronic Structure and Photocatalytic Activity of In (OH) yS z Solid Solution Journal of Physical Chemistry C 112: 16046.

18. Shi HF, Li ZS, Kou J, Ye JH, Zou ZG (2011) Facile synthesis of single-crystalline Ag2V4O11 nanotube material as a novel visible-light-sensitive photocatalyst. Journal of Physical Chemistry C115: 145.

19. Cheng HF, Huang BB, Liu YY, Wang ZY, Qin XY, et al. (2012) An anion exchange approach to Bi 2 WO 6 hollow microspheres with efficient visible light photocatalytic reduction of CO 2 to methanol. Chemical Communications 48: 9729.

20. Hariharan C (2006) Photocatalytic degradation of organic contaminants in water by ZnO nanoparticles: revisited. Appl Catal A Gen 304: 55-61.

21. Mrowetz M, Selli, E (2006) Photocatalytic degradation of formic and benzoic acids and hydrogen peroxide evolution in $\mathrm{TiO} 2$ and $\mathrm{ZnO}$ water suspensions. $J$ Photochem Photobiol A: Chem 180: 15-22.

22. Pauporte T, Rathousky J (2007) Electrodeposited mesoporous $\mathrm{ZnO}$ thin films as efficient photocatalysts for the degradation of dye pollutants. $J$ Phys Chem $C$ 111: 7639-7644.

23. Yu J, Yu X (2008) Hydrothermal synthesis and photocatalytic activity of zinc oxide hollow spheres. Environ Sci Technol 42: 4902-4907. [crossref]

24. Sun JH, Dong SY, Wang YK, Sun SP (2009) Preparation and photocatalytic property of a novel dumbbell-shaped ZnO microcrystal photocatalyst. J Hazard Mater 172: 15201526. [Crossref]

25. Zhou M, Yu J, Cheng B (2008) Preparation, characterization and visible-light-driven photocatalytic activity of $\mathrm{Fe}$-doped titania nanorods and first-principles study for electronic structures. J of Hazard Mater B 137: 1838.

26. Klingshirn C (2007) ZnO: Material, physics and applications. Chemphyschem 8: 782803.

27. Singhal A, Achary S, Tyagi A, Manna A, Yusuf S (2008) Colloidal Fe-doped ZnO nanocrystals: facile low temperature synthesis, characterization and properties. Mater Sci And Eng B 153: 47.

28. Estrellan C, Salim C, Hinode H (2008) Enhancement of photocatalytic activity of ZnO$\mathrm{SiO} 2$ by nano-sized $\mathrm{Ag}$ for visible photocatalytic reduction of $\mathrm{Hg}$ (II). React Kinet Catal Lett 98: 187.

29. Schneider JJ (2008) Enhanced visible light photocatalysis through fast crystallization of zinc oxide nanorods. Adv Mater 13: 529-533.

30. Lee HB, Yoo YM, Han YM (2006) Characteristic optical properties and synthesis of gold-silica core-shell colloids. Scripta Mater 55: 1127-1129.

31. Mohamed RM, Aazam ES (2012) Influence of $\mathrm{Cu}$ doping on structural, optical and photocatalytic activity of $\mathrm{SnO} 2$ nanostructure thin films. Journal of Nanotechnology art. no. 794874 .

32. Ismail AA, Ibrahim IA, Mohamed RM (2006) Enhanced nanocatalysts. Appl Catal B Environ. 45: 161-166

33. Liu T, Wang XR, An Y, Zhou YS, Zhang XY, et al. (2012) Sulphasalazine in patients with rheumatoid arthritis in China: a cross-sectional study. Beijing Da Xue Xue Bao 44: 188-194. [Crossref]

34. Maurice V, Georgelin T, Siaugue JM, Cabuil V (2009) Synthesis and characterization of functionalized core-shell $\gamma \mathrm{Fe} 2 \mathrm{O}$ 3-SiO 2 nanoparticles. J Magn Magn Mater 321: $1408-1413$.

35. Mohamed RM (2009) Characterization and catalytic properties of nano-sized Pt metal catalyst on $\mathrm{TiO} 2-\mathrm{SiO} 2$ synthesized by photo-assisted deposition and impregnation methods. Journal of Materials Processing Technology 209: 577-583.

36. Chou KS, Chen CC (2007) Fabrication and characterization of silver core and porous silica shell nanocomposite particles. Micropor Mesopor Mater 98: 208-213.

37. Mohamed RM, Mkhalid IA (2010) Characterization and catalytic properties of nanosized Ag metal catalyst on $\mathrm{TiO} 2-\mathrm{SiO} 2$ synthesized by photo-assisted deposition and impregnation methods. Journal of Alloys and Compounds 501: 301-306.

38. Height M, Pratsinis S, Mekasuwandumrong O, Praserthdam P, et al. (2006) Ag-ZnO catalysts for UV-photodegradation of methylene blue. Appl Catal B Environ 63: 305.

39. Han T, Wu C, Hsieh C (2007) Hydrothermal synthesis and visible light photocatalysis of metal-doped titania nanoparticles. J Vac Sci Technol B 25: 430.

40. Ullah R, Dutta J (2008) Photocatalytic degradation of organic dyes with manganesedoped ZnO nanoparticles. J Hazard Mater 156: 194-200. [crossref]

41. Slama F, Ghribi F, Houas A, Barthou C, et al. (2010) Structural Properties, Conductivity, Dielectric Studiesand Modulus Formulation of Ni Modified ZnO Nanoparticles. El Mir Int J Nanoelectro and Mater 3: 133.

42. Mohamed RM, Al-Rayyani MA, Baeissa ES, Mkhalid IA (2011) Preparation and characterization of platinum doped porous titania nanoparticles for photocatalytic oxidation of carbon monoxide. Journal of Alloys and Compounds 509 24: 20168246828.

43. Ren C, Yang B, Wu M, Xu J, Fu Z, et al. (2010) Synthesis of Ag/ZnO nanorods array with enhanced photocatalytic performance. J Hazard Mater 182: 123-129. [crossref]

44. Lai Y, Meng M, Yu Y (2010) ne-step synthesis, characterizations and mechanistic study of nanosheets-constructed fluffy $\mathrm{ZnO}$ and $\mathrm{Ag} / \mathrm{ZnO}$ spheres used for Rhodamine $\mathrm{B}$ photodegradation. Appl Catal B Environ 100: 491-501.

45. Mohamed RM, McKinney DL, Sigmund WM, et al. (2012) Enhanced nanocatalysts. Materials Science \& Engineering R-Reports 73: 1.

46. Yuan M, Zhang J, Yan S, Luo G, Xu Q, Wang X, et al. (2011) Effect of Nd 2 O 3 addition on the surface phase of TiO 2 and photocatalytic activity studied by UV Raman spectroscopy. Journal of Alloys and Compounds 509: 6227.

47. Yao N, Cao S, Yeung M (2009) Mesoporous TiO 2-SiO 2 aerogels with hierarchal pore structures. Microporous and Mesoporous Materials 117: 570.

48. Tel H, Altas Y, Eral M, Sert S, Cetinkaya B, Inan S (2010) Preparation of ZrO 2 and $\mathrm{ZrO} 2-\mathrm{TiO} 2$ microspheres by the sol-gel method and an experimental design approach to their strontium adsorption behaviours. Chemical Engineering Journal 161: 151.

49. Yamazaki S, Fujiwara Y, Yabuno S, Adachi K, Honda K (2012) Synthesis of porous platinum-ion-doped titanium dioxide and the photocatalytic degradation of 4-chlorophenol under visible light irradiation. Applied Catalysis B-Environmental 121 148

50. Karunakaran C, Dhanalakshmi R, Gomathisankar P (2012) Phenol-photodegradation on $\mathrm{ZrO} 2$. Enhancement by semiconductors. Spectrochim Acta A Mol Biomol Spectrosc 92: 201-206. [crossref]

Copyright: (C2016 Baeissa ES. This is an open-access article distributed under the terms of the Creative Commons Attribution License, which permits unrestricted use, distribution, and reproduction in any medium, provided the original author and source are credited. 